\title{
Prescribing cascades in older adults
}

\author{
Shelley A. Sternberg MD, Shiri Guy-Alfandary PharmD, Paula A. Rochon MD
}

Cite as: CMAJ 2021 February 8;193:E215. doi: 10.1503/cmaj.201564

CMAJ Podcasts: author interview at www.cmaj.ca/lookup/doi/10.1503/cmaj.201564/tab-related-content

1

A prescribing cascade refers to the sequence of events in which an adverse drug event is misinterpreted as a new medical condition, leading to the addition of another, potentially avoidable, medication ${ }^{1}$

For example, calcium channel blockers may cause ankle edema for which a diuretic may be prescribed. In a cohort study, this particular cascade occurred in $9.5 \%$ of older adults who were newly prescribed a calcium channel blocker (Appendix 1, available at www.cmaj.ca/ lookup/doi/10.1503/cmaj.201564/tab-related-content). ${ }^{2}$

2 Serious adverse events can result in admission to hospital In one case, a patient developed a cough after starting an angiotensinconverting-enzyme inhibitor. A cough syrup with guafenasin and codeine was prescribed, leading to lethargy. ${ }^{3}$ Levofloxacin was started for presumed pneumonia, which led to diarrhea, followed by delirium and admission to hospital.

\section{3}

\section{Cascades contribute to inappropriate polypharmacy,}

particularly in older adults

Patients with chronic conditions and geriatric syndromes that require complex drug regimens are at increased risk for problematic and inappropriate polypharmacy. ${ }^{4}$

\section{4}

\section{Cascades can be identified and inappropriate \\ polypharmacy prevented ${ }^{1}$}

Prescribers should ask themselves, "Is the patient reporting a symptom that could represent an adverse drug event?" and "Is a new drug being considered to address an adverse event that may relate to a previously prescribed drug therapy?" If the answer to either question is yes, prescribers should ask, "Could the initial drug be substituted for a safer alternative or could the dose be reduced, potentially eliminating the need for the subsequent drug therapy?" and "Does the patient need the initial drug therapy or could it be stopped?"

\section{Consider deprescribing when a cascade is identified}

Deprescribing is the process of tapering or stopping drugs that may not be indicated, according to patients' priorities, to minimize polypharmacy and improve patient outcomes. ${ }^{5}$

\section{References}

1. Rochon PA, Gurwitz JH. The prescribing cascade revisited. Lancet 2017;389:1778-80

2. Savage RD, Visentin JD, Bronskill SE, et al. Evaluation of a common prescribing cascade of calcium channel blockers and diuretics in older adults with hypertension. JAMA Intern Med 2020; 180:643-51.

3. Liu PT, Argento VS, Skudlarska BA. Prescribing cascade in an 80-year-old Japanese immigrant. Geriatr Gerontol Int 2009;9:402-4.

4. Duerden M, Avery T, Payne R. Polypharmacy and medicines optimization: making it safe and sound. London: The King's Fund; 2013. Available: www.kingsfund.org.uk/sites/files/kf/field/field_publication_ file/polypharmacy-and-medicines-optimisation-kingsfund-nov13. pdf (accessed 2020 June 16).

5. Scott IA, Hilmer SN, Reeve E, et al. Reducing inappropriate polypharmacy: the process of deprescribing. JAMA Intern Med 2015; 175:827-34.

\section{Competing interests: None declared.}

This article has been peer reviewed.

Affiliations: Maccabi Healthcare Services (Sternberg), Modiin, Israel; Maccabi Healthcare Services (Guy-Alfandary), Tel Aviv, Israel; Women's College Hospital (Rochon), University of Toronto, Toronto, Ont.

Content licence: This is an Open Access article distributed in accordance with the terms of the Creative Commons Attribution (CC BY-NC-ND 4.0) licence, which permits use, distribution and reproduction in any medium, provided that the original publication is properly cited, the use is noncommercial (i.e., research or educational use), and no modifications or adaptations are made. See: https://creativecommons.org/licenses/by-nc-nd/4.0/

Funding: The iKascade project is funded by GENDER NET Plus (GNP-1782) in partnership with the Canadian Institutes of Health Research (Institute of Gender \& Health and Institute of Aging), the Irish Research Council, Ministero della Salute (Italy) and the Ministry of Science, Technology and Space (Israel).

Correspondence to: Shelley Sternberg, sternb_sh@mac.org.il 